\title{
TEHNIK DATA MINING DALAM MENGELOMPOKKAN KASUS PNEUMONIA PADA BALITA BERDASARKAN PROVINSI DI INDONESIA
}

\author{
Puji Hariyati $^{1}$, Saifullah ${ }^{2}$, M.Fauzan ${ }^{3}$ \\ ${ }^{1}$ Mahasiswa STIKOM Tunas Bangsa, Pematangsiantar, Indonesia \\ ${ }^{2,3}$ Dosen STIKOM Tunas Bangsa, Pematangsiantar, Indonesia \\ Email: ${ }^{1}$ pujihariyati7@gmail.com, ${ }^{2}$ Saifullah@stikomtunasbangsa.ac.id, ${ }^{3}$ M.Fauzan@ stikomtunasbangsa.ac.id
}

\begin{abstract}
Abstrak
Pneumonia adalah penyakit infeksi yang menyerang paru, sehingga menyebabkan kantung udara di dalam paru meradang dan membengkak. Kondisi kesehatan ini sering disebut paru-paru basah. Kondisi paru-paru basah dapat di alami oleh siapa pun yang disebabkan oleh bakteri, virus, dan jamur yang mudah ditularkan melalui udara dalam kondisi bersin atau batuk. Namun Pneumonia pada anak bisa sangat berbahaya dan menyebabkan kematian. Penelitian ini bertujuan untuk membuat sebuah model pengelompokan menggunakan algoritma K-Means. Metode yang digunakan adalah Datamining Clustering K-Means. Dengan menggunakan Algoritma ini data yang telah dihasilkan dapat dikelompokkan kedalam Cluster berdasarkan data-data tersebut. Data bersumber dari Departemen Kesehatan indonesia pada tahun 2017. Jumlah record yang digunakan sebanyak 34 Provinsi yang di bagi kedalam 2 cluster yakni cluster tinggi dan cluster rendah. Dari hasil perhitungan $K$-Means di peroleh sebanyak 3 Provinsi sebagai cluster tertinggi dan 31 Provinsi sebagai cluster rendah. Proses implementasi menggunakan aplikasi Rapidminer 5.3 digunakan untuk membantu menemukan nilai yang akurat. Diharapkan dengan adanya penelitian ini dapat dijadikan rujukan kepada pemerintah dalam menanggulangi penyakit pneumonia khususnya pada balita untuk dapat meningkatkan pelayanan kesehatan, penyediaan obat, serta peralatan untuk perawatan dan mengantisipasi terhadap penyakit Pneumonia pada provinsi di Indonesia.
\end{abstract}

Kata Kunci: Pneumonia, Algoritma K-Means, Data Mining

\begin{abstract}
Pneumonia is an infectious disease that attacks the lungs, causing air sacs in the lungs to become inflamed and swollen. This health condition is often called a wet lung. The condition of a wet lung can be experienced by anyone caused by bacteria, viruses, and fungi that are easily transmitted through the air in sneezing or coughing conditions. But pneumonia in children can be very dangerous and cause death. This study aims to create a grouping model using the K-Means algorithm. The method used is Datamining Clustering K-Means. By using this algorithm the data that has been generated can be grouped into clusters based on these data. The data is sourced from the Indonesian Ministry of Health in 2017. The number of records used is 34 provinces divided into 2 clusters namely high and low clusters. From the calculation of K-Means, there were 3 provinces as the highest cluster and 31 provinces as a low cluster. The implementation process using the Rapidminer 5.3 application is used to help find accurate values. It is expected that with this research can be used as a reference to the government in tackling pneumonia especially in infants to be able to improve health services, supply drugs, and equipment for treatment and anticipate against pneumonia in provinces in Indonesia.
\end{abstract}

Keywords: Pneumonia, K-Means Algorithm, Data Mining

\section{PENDAHULUAN}

Pneumonia adalah penyakit infeksi yang menyerang paru, sehingga menyebabkan kantung udara di dalam paru meradang dan membengkak. Kondisi kesehatan ini sering disebut paru-paru basah, sebab paru bisa saja di penuhi dengan air atau cairan lendir. Kondisi paru-paru basah dapat di alami oleh siapa pun yang disebabkan oleh bakteri, virus, dan jamur yang mudah ditularkan melalui udara dalam kondisi bersin atau batuk. Namun Pneumonia pada anak bisa sangat berbahaya dan menyebabkan kematian.

Pneumonia merupakan masalah kesehatan di dunia dengan angka kematian tinggi baik di negara berkembang maupun di negara maju seperti Amerika Serikat, Kanada dan negara-negara Eropa. Berdasarkan data WHO (World Health Organization) tahun 2015 hampir 6 juta anak balita meninggal di dunia $16 \%$ dari jumlah tersebut di sebabkan oleh Pneumonia sebagai pembunuh nomor 1 di dunia dan data UNICEF 2015 sekitar $14 \%$ dari 147.000 anak meninggal di bawah usia 5 tahun karena Pneumonia. Dari statistik tersebut, dapat di artikan sebanyak 2 sampai 3 anak di bawah usia 5 tahun meninggal karena Pneumonia setiap jamnya. Hal tersebut menyebabkan Pneumonia sebagai penyebab kematian utama anak di bawah 5 tahun di Indonesia. Saat ini, Indonesia menduduki peringkat 10 di dunia dalam kasus kematian balita akibat Pneumonia. Seiring perkembangan zaman hal ini butuh penanganan serius oleh pemerintah dalam mengurangi peningkatan Pneumonia di Indonesia dan menghindari tingkat tinggi Pneumonia seperti negara-negara lain.

Banyak cabang ilmu komputer dapat memecahkan masalah yang kompleks, salah satunya data mining. Berdasarkan Penelitian terdahulu yang dilakukan oleh [1] yang berjudul "Data Mining : Penerapan Rapidminer Dengan K-Means Cluster Pada Daerah Terjangkit Demam Berdarah Dengue (DBD) Berdasarkan Provinsi”. Pada penelitiannya yang telah dilakukan, Dari 34 data jumlah kasus yang terjangkit Demam Berdarah Dengue (DBD) berdasarkan provinsi dapat diketahui, 4 provinsi cluster tinsgkat tinggi untuk penderita kasus DBD yakni Sumatera Utara, Jawa Barat, Jawa Tengah dan Jawa Timur, 13 provinsi cluster tingkat sedang dan 17 provinsi lainnya termasuk cluster tingkat rendah. Penelitian selanjutnya dilakukan oleh [2], yang berjudul "Clustering Menggunakan Metode $K$ - 
Means Untuk Menentukan Status Gizi Balita". Pada penelitiannya yang telah dilakukan, dengan membandingkan hasil pengelompokan menggunakan tabel Growth Chart dan algoritma K-Means didapat 17 data yang memiliki kelompok yang sama. Dari angka ini dapat disimpulkan bahwa algoritma K-Means hanya memiliki nilai akurasi 34\% benar. Nilai ini bisa berubah seiring dengan penambahan data latih. Penelitian ini menjadi salah satu acuan penulis dalam melakukan penelitian sehingga penulis dapat memperkaya teori yang digunakan dalam mengkaji penelitian yang dilakukan. Dari penelitian terdahulu, penulis tidak menemukan penelitian dengan judul yang sama seperti judul penelitian penulis. Namun penulis mengangkat beberapa penelitian sebagai referensi dalam memperkaya bahan kajian pada penelitian penulis.

Untuk mengetahui tingkat Pneumonia di Indonesia penulis menggunakan teknik data mining dalam proses pengolahan data dengan metode k-means. Data yang di teliti selanjutnya di kelompokan dan diuji menggunakan Rapidminer versi 5.3 pada pengelompokkan Pneumonia dari 34 Provinsi di Indonesia. Diharapkan dengan adanya penelitian ini dapat dijadikan rujukan kepada pemerintah dalam menanggulangi penyakit pneumonia khususnya pada balita untuk dapat meningkatkan pelayanan kesehatan, penyediaan obat, serta peralatan untuk perawatan dan mengantisipasi terhadap penyakit Pneumonia pada provinsi di Indonesia.

\section{TEORITIS}

\subsection{Data Mining}

Data mining merupakan proses menemukan korelasi baru yang bermanfaat, pola dan trend dengan menambang sejumlah repository data dalam jumlah besar, menggunakan teknologi pengenalan pola seperti statistik dan teknik matematika. Data mining disebut juga dengan knowledge discovery in database (KDD) ataupun pattern recognition [1].

\subsection{Pneumonia}

Pneumonia adalah penyakit infeksi akut yang mengenai jaringan paru (alveoli) dengan gejala umum pada anakanak dan bayi yaitu napas cepat atau sulit, batuk, demam, menggigil, sakit kepala, kehilangan nafsu makan dan mengimengi. Pneumonia merupakan pembunuh utama balita di dunia, lebih banyak dibandingkan dengan penyakit lain seperti AIDS, Malaria dan Campak. Di dunia setiap tahun diperkirakan lebih dari 2 juta balita meninggal karena pneumonia dari 9 juta total kematian balita. Setiap 5 kematian balita satu diantaranya disebabkan oleh pneumonia. Sebagian besar terjadi di negara berkembang, 70\% terdapat di Afrika dan Asia Tenggara. Di negara berkembang $60 \%$ kasus pneumonia disebabkan oleh bakteri, sementara di negara maju umumnya disebabkan oleh virus [3].

\subsection{Algoritma K-Means}

Algoritma K-Means merupakan Algoritma pengelompokan iteratif yang melakukan partisi set data kedalam sejumlah $K$ cluster yang sudah ditetapkan diawal. Algoritma $K$-Means sederhana untuk diimplementasikan dan dijalankan, relative cepat, mudah beradaptasi, umum penggunaannya dalam praktek. Secara historis, $K$-Means menjadi salah satu algoritma yang paling penting dalam bidang data mining.

Algoritma K-means adalah algoritma yang terbaik dalam algoritma partitional clustering dan yang paling sering digunakan diantara algoritma clustering lainnya kerena kesederhanaan dan efisiensinya. Kelebihan Algoritma $K$ means itu sendiri menurut K. Arai and A. R. Barakbah, merupakan algoritma clustering yang paling sederhana dan umum, hal ini dikarenakan $K$-means mempunyai kemampuan mengelompokkan data dalam jumlah yang cukup besar dengan waktu komputasi yang relatif cepat dan efisien. Namun, K-means mempunyai kelemahan yang diakibatkan oleh penentuan pusat awal cluster [4].

Berikut ini adalah langkah-langkah dalam algoritma K-means [5] :

1. Tentukan jumlah cluster $(\mathrm{k})$ pada data set

2. Tentukan nilai pusat (centroid)

Penentuan nilai centroid pada tahap awal dilakukan secara random, sedangkan pada tahap iterasi digunakan rumus seperti pada persamaan (1) berikut ini :

$\mathrm{V}_{\mathrm{ij}}=\frac{1}{N i} \sum_{k=0}^{N i} X k j$

Keterangan :

$\mathrm{V}_{\mathrm{ij}}=$ centroid rata-rata cluster $\mathrm{ke}-\mathrm{I}$ untuk variabel ke-j

$\mathrm{N}_{\mathrm{i}} \quad$ = Jumlah anggota cluster ke-i

$\mathrm{i}, k=$ indeks dari cluster

$\mathrm{j}=$ indeks dari variabel

Xkj = nilai data ke-k variabel ke-j untuk cluster tersebut

3. Pada masing-masing record, hitung jarak terdekat dengan centroid. Jarak centroid yang digunakan adalah Euclidean Distance, dengan rumus seperti dibawah ini:

$D\left(x_{2}, x_{1}\right)=\left\|x_{2}-x_{1}\right\|_{2}$ 
$\sqrt{\sum_{j=1}^{p}\left|x_{2 j}-x_{1 j}\right|^{2}}$

Keterangan:

$D=$ Euclidean Distance

$x \quad=$ banyaknya objek

$\Sigma \mathrm{p} \quad=$ jumlah data record

$D e=\sqrt{(x i-s i)^{2}+(y i-t i)^{2}}$

Keterangan :

De $=$ Eulidean Distance

$\mathrm{i} \quad=$ Banyaknya objek ${ }^{2}$

$(\mathrm{x}, \mathrm{y})=$ Koordinat objek

$(\mathrm{s}, \mathrm{t})=$ Koordinat centroid

4. Kelompokkan objek berdasarkan jarak ke centroid terdekat

5. Ulangi langkah ke-2, lakukan iterasi hingga centroid bernilai optimal

\section{ANALISA DAN PEMBAHASAN}

\subsection{Tahap Pengumpulan Data}

Dalam hal ini variabel data yang ingin di cluster adalah nilai rata-rata tahun 2017 sebagai data yang akan di cluster. Jumlah sampel data pneumonia yang akan digunakan dalam penelitian ini adalah sebanyak 34 provinsi. Berikut adalah langkah-langkah penyelesaian yang dilakukan peneliti dalam mengelompokkan Kasus Pneumonia Pada Balita pada tahun 2017 yang di peroleh dari Departemen Kesehatan atau situs resmi http://www.depkes.go.id menggunakan algoritma $K$-means.

Berikut ini adalah data penyakit Pneumonia yang peneliti ambil dari data situs Departemen Kesehatan :

Tabel 1. Data Penyakit Pneumonia Menurut Provinsi

\begin{tabular}{llll}
\hline & Provinsi & Jumlah & \% \\
\hline 1 & Aceh & 2157 & 9,91 \\
2 & Sumatera Utara & 5398 & 12,88 \\
3 & Sumatera Barat & 10576 & 51,43 \\
4 & Riau & 6149 & 37,39 \\
5 & Jambi & 4953 & 45,46 \\
6 & Sumatera Selatan & 12338 & 41,68 \\
7 & Bengkulu & 493 & 12,76 \\
8 & Lampung & 6273 & 35,09 \\
9 & Kepulauan Bangka Belitung & 5591 & 67,21 \\
10 & Kepulauan Riau & 1265 & 15,21 \\
11 & DKI Jakarta & 43500 & 98,66 \\
12 & Jawa Barat & 126936 & 61,59 \\
13 & Jawa Tengah & 52033 & 52,49 \\
14 & DI Yogyakarta & 1155 & 7,35 \\
15 & Jawa Timur & 65139 & 41,93 \\
16 & Banten & 30402 & 62,35 \\
17 & Bali & 5275 & 63,11 \\
18 & Nusa Tenggara Barat & 18569 & 59,16 \\
19 & Nusa Tenggara Timur & 0 & 0 \\
20 & Kalimantan Barat & 1683 & 16,65 \\
21 & Kalimantan Tengah & 471 & 4,12 \\
22 & Kalimantan Selatan & 14675 & 66,72 \\
23 & Kalimantan Timur & 6780 & 33,68 \\
24 & Kalimantan Utara & 1431 & 74,76 \\
25 & Sulawesi Utara & 292 & 4,65 \\
26 & Sulawesi Tengah & 8326 & 66,59 \\
27 & Sulawesi Selatan & 6120 & 19,27 \\
28 & Sulawesi Tenggara & 2577 & 26,64 \\
29 & Gorontalo & 2985 & 47,89 \\
30 & Sulawesi Barat & 1815 & 28,91 \\
31 & Maluku & 1050 & 18,33 \\
32 & Maluku Utara & 971 & 36,48 \\
33 & Papua Barat & 0 & 0 \\
& & &
\end{tabular}




$$
34 \text { Papua } 53 \quad 0,6
$$

\subsection{Perhitungan Algoritma K-Means}

Untuk mendapatkan hail penelitian selanjutnya data dimasukkan dalam metode clustering dengan menerapkan tahapan $K$-means dengan aplikasi Rapidminer untuk melakukan proses pengclusteran data menjadi 2 cluster, untuk mendapatkan hasil dengan nilai cluster tertinggi dan cluster terendah.

1. Menentukan Titik Centroid

Untuk proses penentuan titik Centroid data yang akan diinginkan adalah 2, penentuan cluster dibagi atas 2 yakni cluster tingkat tertinggi (C1), cluster tingkat terendah (C2). Untuk nilai cluster tertinggi didapat dari nilai terbesar, sedangkan untuk cluster terendah diambil dari nilai terkecil. Nilai centroid tersebutdapat dilihat pada tabel berikut

Tabel 2. Centroid Awal

\begin{tabular}{llll}
\hline \multirow{2}{*}{ Centroid } & C1/x (Max) & 126936 & 98.66 \\
& C2/y (Min) & 0 & 0 \\
\hline
\end{tabular}

2. Menghitung Jarak Centroid

Pada tahap ini akan dilakukan perhitungan jarak antar titik Centroid dengan tiap objek menggunakan rumus Eucldian Distance, yaitu sebagai berikut :

$D e=\sqrt{(x i-s i)^{2}+(y i-t i)^{2}}$

Maka perhitungan pada jarak Centroid pertama adalah sbb :

$\mathrm{D}_{\mathrm{A} 1, \mathrm{c} 1}=\sqrt{(2157-126936)^{2}+(9,91-98,66)^{2}}=124779$

$\mathrm{D}_{\mathrm{A} 2, \mathrm{c} 2}=\sqrt{(5398-126936)^{2}+(12,88-98,66)^{2}}=121538$

$\mathrm{D}_{\mathrm{A} 3, \mathrm{c} 3}=\sqrt{(10576-126936)^{2}+(51,43-98,66)^{2}}=116360$

$\mathrm{D}_{\mathrm{A} 4, \mathrm{c} 4}=\sqrt{(6149-126936)^{2}+(37,39-98,66)^{2}}=120787$

$\mathrm{D}_{\mathrm{A} 5, \mathrm{c} 5}=\sqrt{(4953-126936)^{2}+(45,46-98,66)^{2}}=121938$

Seterusnya dilakukan perhitungan dengan cara yang sama sampai alternatif terakhir. Kemudian melakukan perhitungan untuk jarak dari Centroid kedua adalah sbb :

$\mathrm{D}_{\mathrm{A} 1, \mathrm{c} 2}=\sqrt{(2157-0)^{2}+(9,91-0)^{2}}=2158$

$\mathrm{D}_{\mathrm{A} 2, \mathrm{c} 2}=\sqrt{(5398-0)^{2}+(12,88-0)^{2}}=5398$

$\mathrm{D}_{\mathrm{A} 3, \mathrm{c} 3}=\sqrt{(10576-0)^{2}+(51,43-0)^{2}}=10576$

$\mathrm{D}_{\mathrm{A} 4, \mathrm{c} 4}=\sqrt{(6149-0)^{2}+(37,39-0)^{2}}=6149$

$\mathrm{D}_{\mathrm{A} 5, \mathrm{c} 5}=\sqrt{(4953-0)^{2}+(45,46-0)^{2}}=4953$

Seterusnya sampai dengan alternatif terakhir. Maka akan didapatkan hasil dari jarak terpendek dari Centroid, dengan melihat peryataan berikut. "Jika nilai jarak terpendek berada di kolom C1 maka pada kolom C1 dibri nilai 1" dan "Jika jarak terpendek berada di kolom C2 maka pada kolom C2 di beri nilai 1" dan mencari nilai yang sama pada kedua Centroid. Dapat dilihat pada tabel berikut :

Tabel 3. Hasil Perhitungan di Iterasi Ke-1

\begin{tabular}{llllll}
\hline C1 & C2 & Jarak Terpendek & No. & C1 & C2 \\
\hline 124779 & 2157 & 2157 & 1 & 1 \\
121538 & 5398 & 5398 & 2 & 1 \\
116360 & 10576 & 10576 & 3 & 1 \\
120787 & 6149 & 6149 & 4 & 1 \\
121983 & 4953 & 4953 & 5 & 1 \\
114598 & 12338 & 12338 & 6 & 1 \\
126443 & 493 & 493 & 7 & 1 \\
120663 & 6273 & 6273 & 8 & 1 \\
121345 & 5591 & 5591 & 9 & 1 \\
125671 & 1265 & 1265 & 10 & 1 \\
83436 & 43500 & 43500 & 11 & 1 \\
37 & 126936 & 37 & 12 & 1 & \\
74903 & 52033 & 52033 & 13 & 1 \\
125781 & 1155 & 1155 & 14 & 1 \\
61797 & 65139 & 61797 & 15 & 1 & \\
96534 & 30402 & 30402 & 16 & 1 \\
121661 & 5275 & 5275 & 17 & 1 \\
108367 & 18569 & 18569 & 18 & 1
\end{tabular}




\begin{tabular}{lllll}
\hline 126936 & 0 & 0 & 19 & 1 \\
125253 & 1683 & 1683 & 20 & 1 \\
126465 & 471 & 471 & 21 & 1 \\
112261 & 14675 & 14675 & 22 & 1 \\
120156 & 6780 & 6780 & 23 & 1 \\
125505 & 1433 & 1433 & 24 & 1 \\
126644 & 292 & 292 & 25 & 1 \\
118610 & 8326 & 8326 & 26 & 1 \\
120816 & 6120 & 6120 & 27 & 1 \\
124359 & 2577 & 2577 & 28 & 1 \\
123951 & 2985 & 2985 & 29 & 1 \\
125121 & 1815 & 1815 & 30 & 1 \\
125886 & 1050 & 1050 & 31 & 1 \\
125965 & 972 & 972 & 32 & 1 \\
126936 & 0 & 0 & 33 & 1 \\
126883 & 53 & 53 & 34 & 1 \\
\hline
\end{tabular}

3. Menentukan posisi Cluster (Pengelompokkan)

Pada tahapan ini akan dilakukan penentuan cluster dengan nilai pada cluster dari nilai yang sama dan diletakkan pada cluster yang sesuai dengan nilai yang sama di Iterasi pertama. Kemudian dalam proses perhitungan $K$-Means, perhitungan akan berhenti jika cluster pada iterasi yang dihasilkan oleh nilai sebelumnya bernilai sama. Selanjutnya untuk mencari mencari nilai Centroid baru adalah dengan cara menambahkan (menjumlah) nilai yang terpilih pada nilai Cluster kemudian membagikan nya sebanyak jumlah nilai. Caranya sebagai berikut:

$\mathrm{C} 1=(126936+65139) / 2=96037,5$

$\mathrm{C} 2=(9,91+12,18+51,43+37,39+45,46+41,68+12,76+35,09+67,21+15,21+98,66+52,49+7,35+$ $62,35+63,11+59,16+0+16,65+4,12+66,72+33,68+74,76+4,65+66,59+19,27+26,64+47,89+$ $28,91+18,33+36,48+0+0,6) / 32=34.91969$

Maka akan mendapatkan nilai Centroid baru di Iterasi pertama sbb :

Tabel 4. Centroid Iterasi Ke-2

\begin{tabular}{llll}
\hline \multirow{2}{*}{ Centroid } & C1 & 96037.5 & 51.76 \\
& C2 & 7979.875 & 34.91969 \\
\hline
\end{tabular}

Selanjutnya menghitung Centroid di Iterasi kedua dengan menggunakan rumus yang sama seperti sebelumnya untuk menentukan jarak Centroid, Maka berikut hasil dari jarak Centroid :

Tabel 5. Hasil Perhitungan di Iterasi Ke-2

\begin{tabular}{cccccc}
\hline C1 & C2 & Jarak Terpendek & No. & C1 & C2 \\
\hline 93881 & 5823 & 5823 & 1 & 1 \\
90640 & 2582 & 2582 & 2 & 1 \\
85462 & 2596 & 2596 & 3 & 1 \\
89889 & 1831 & 1831 & 4 & 1 \\
91085 & 3027 & 3027 & 5 & 1 \\
83700 & 4358 & 4358 & 6 & 1 \\
95545 & 7487 & 7487 & 7 & 1 \\
89765 & 1707 & 1707 & 8 & & 1 \\
90447 & 2389 & 2389 & 9 & & 1 \\
94773 & 6715 & 6715 & 10 & \\
52538 & 35520 & 35520 & 11 & & 1 \\
30899 & 118956 & 30899 & 12 & 1 & \\
44005 & 44053 & 44005 & 13 & 1 & \\
94883 & 6825 & 6825 & 14 & & 1 \\
30899 & 57159 & 30899 & 15 & 1 & \\
65636 & 22422 & 22422 & 16 & & 1 \\
90763 & 2705 & 2705 & 17 & 1 \\
77469 & 10589 & 10589 & 18 & & 1 \\
96038 & 7980 & 7980 & 19 & 1 \\
94355 & 6297 & 6297 & 20 & 1 \\
95567 & 7509 & 7509 & 21 & 1 \\
81363 & 6695 & 6695 & 22 & 1 \\
\hline & & & &
\end{tabular}




\begin{tabular}{ccccc}
\hline 89258 & 1200 & 1200 & 23 & 1 \\
94607 & 6549 & 6549 & 24 & 1 \\
95746 & 7688 & 7688 & 25 & 1 \\
87712 & 348 & 348 & 26 & 1 \\
89918 & 1860 & 1860 & 27 & 1 \\
93461 & 5403 & 5403 & 28 & 1 \\
93053 & 4995 & 4995 & 29 & 1 \\
94223 & 6165 & 6165 & 30 & 1 \\
94988 & 6930 & 6930 & 31 & 1 \\
95067 & 7009 & 7009 & 32 & 1 \\
96038 & 7980 & 7980 & 33 & 1 \\
95985 & 7927 & 7927 & 34 & 1 \\
\hline
\end{tabular}

Jika hasil dari perhitungan di Iterasi pertama dan kedua nilai Centroid nya belum sama, maka perhitungan akan berlanjut pada iterasi ketiga dengan cara yang sama seperti sebelumnya sbb :

$\mathrm{C} 1=(126936+52033+65139) / 3=81369$

$\mathrm{C} 2=(9,91+12,88+51,43+37,39+45,46+41,68+12,76+35,09+67,21+15,21+98,66+7,35+62,35+$ $63,11+59,16+0+16,65+4,12+66,72+33,68+74,76+4,65+66,59+19,27+26,64+47,89+28,91+18,33$ $+36,48+0+0,6=6558,8$

Maka akan mendapatkan nilai Centroid baru di Iterasi ketiga sbb :

Tabel 6. Centroid Iterasi Ke-3

\begin{tabular}{llll}
\hline \multirow{2}{*}{ Centroid } & C1 & 81369.33 & 52.00333 \\
& C2 & 6558.806 & 34.3529 \\
\hline
\end{tabular}

Tabel 3.7. Hasil Perhitungan di Iterasi Ke-3

\begin{tabular}{|c|c|c|c|c|c|}
\hline C1 & $\mathbf{C 2}$ & Jarak Terpendek & No. & C1 & $\mathrm{C2}$ \\
\hline 79212 & 4402 & 4402 & 1 & & 1 \\
\hline 75971 & 1161 & 1161 & 2 & & 1 \\
\hline 70793 & 4017 & 4017 & 3 & & 1 \\
\hline 75220 & 410 & 410 & 4 & & 1 \\
\hline 76416 & 1606 & 1606 & 5 & & 1 \\
\hline 69031 & 5779 & 5779 & 6 & & 1 \\
\hline 80876 & 6066 & 6066 & 7 & & 1 \\
\hline 75096 & 286 & 286 & 8 & & 1 \\
\hline 75778 & 968 & 968 & 9 & & 1 \\
\hline 80104 & 5294 & 5294 & 10 & & 1 \\
\hline 37869 & 36941 & 36941 & 11 & & 1 \\
\hline 45567 & 120377 & 45567 & 12 & 1 & \\
\hline 29336 & 45474 & 29336 & 13 & 1 & \\
\hline 80214 & 5404 & 5404 & 14 & & 1 \\
\hline 16230 & 58580 & 16230 & 15 & 1 & \\
\hline 50967 & 23843 & 23843 & 16 & & 1 \\
\hline 76094 & 1284 & 1284 & 17 & & 1 \\
\hline 62800 & 12010 & 12010 & 18 & & 1 \\
\hline 81369 & 6559 & 6559 & 19 & & 1 \\
\hline 79686 & 4876 & 4876 & 20 & & 1 \\
\hline 80898 & 6088 & 6088 & 21 & & 1 \\
\hline 66694 & 8116 & 8116 & 22 & & 1 \\
\hline 74589 & 221 & 221 & 23 & & 1 \\
\hline
\end{tabular}




\begin{tabular}{lllll}
79938 & 5128 & 5128 & 24 & 1 \\
81077 & 6267 & 6267 & 25 & 1 \\
73043 & 1767 & 1767 & 26 & 1 \\
75249 & 439 & 439 & 27 & 1 \\
78792 & 3982 & 3982 & 28 & 1 \\
78384 & 3574 & 3574 & 29 & 1 \\
79554 & 4744 & 4744 & 30 & 1 \\
80319 & 5509 & 5509 & 31 & 1 \\
80398 & 5588 & 5588 & 32 & 1 \\
81369 & 6559 & 6559 & 33 & 1 \\
81316 & 6506 & 6506 & 34 & 1 \\
\hline
\end{tabular}

Dari hasil perhitungan diatas pada tabel Cluster Iterasi ke-2 dan Iterasi ke-3 memiliki nilai Cluster yang sama dan nilai nya tidak berubah di Cluster terakhir. Maka hasil yang didapatkan pada Cluster pertama (C1) adalah berjumlah 3 Provinsi yang termasuk kedalam kategori Penyakit Pneumonia tertinggi di provinsi Indonesia. Untuk Cluster kedua (C2) mendapatkan 33 provinsi yang termasuk kedalam kategori Penyakit Pneumonia terendah di provinsi Indonesia.

\subsection{Tampilan Rapidminer} ini

Sehingga berdasarkan data hasil clustering pada pehitungan didapatkan grafik hasil dari rapidminer 5.3 berikut

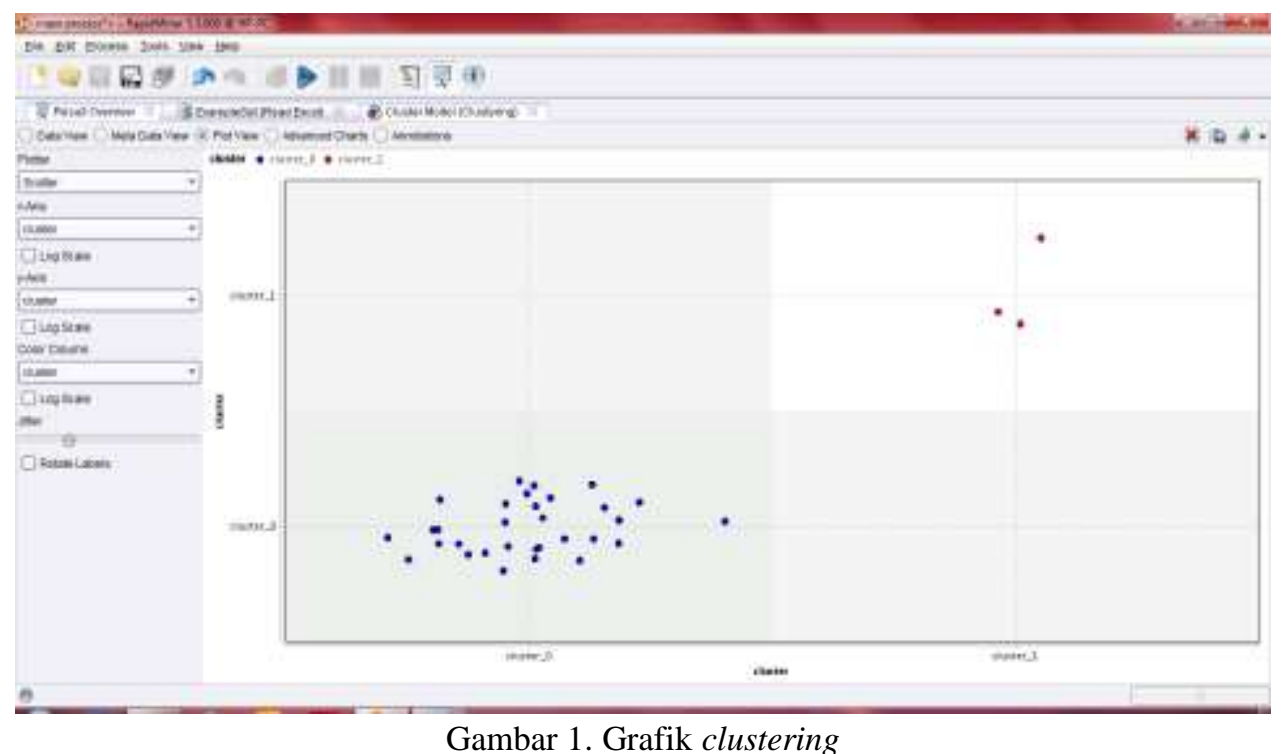

Dari hasil implementasi di rapidminer diketahui bahwa titik berwarna merah adalah cluster 1 , dan titik berwarna biru adalah cluster 0 . Hasil pengklasteran pada cluster 1 (tertinggi) berjumlah 3 provinsi yaitu Jawa Tengah, Jawa Barat, Jawa Timur dan pada cluster 0 (terendah) berjumlah 31 provinsi.

\section{KESIMPULAN}

Berdasarkan hasil dari pembahasan diatas, penulis mengambil kesimpulan sebagai berikut :

1. Keilmuan yang digunakan adalah Data Mining dengan Algoritma k-means clustering untuk mengelompokkan jumlah provinsi yang banyak terkena penyakit Pneumonia.

2. Pengimplementasian dilakukan dengan menggunakan bantuan software Rapidminer 5.3 sehingga mendapatkan hasil yang serupa dengan perhitungan manual di microsoft excel.

3. Hasil di dapat untuk cluster tertinggi C1 sebanyak 3 provinsi yaitu provinsi (Jawa Barat, Jawa Tengah, Jawa Timur), dan hasil untuk cluster terendah pada $\mathrm{C} 2$ adalah sebanyak 31 Provinsi yaitu (Aceh, Sumatera Utara, Sumatera Barat, Riau, Jambi, Sumatera Selatan, Bengkulu, Lampung, Kep. Bangka Belitung, Kepualuan Riau, DKI Jakarta, DI Yogyakarta, Banten, Bali, NTB, NTT, Kalimantan Barat, Kalimantan Tengah, Kalimantan Timur, 
Kalimantan Utara, Sulawesi Utara, Sulawesi Tengah, Sulawesi Tenggara, Gorontalo, Sulawesi Barat, Maluku, Maluku Utara, Papua Barat, Papua).

\section{REFERENCES}

[1] K. Fatmawati and A. P. Windarto, "DATA MINING: PENERAPAN RAPIDMINER DENGAN K-MEANS CLUSTER PADA DAERAH TERJANGKIT DEMAM BERDARAH DENGUE ( DBD ) BERDASARKAN PROVINSI,” vol. 3, no. 2, pp. 173-178, 2018.

[2] W. M. P. Dhuhita, “CLUSTERING MENGGUNAKAN METODE K-MEANS UNTUK,” vol. 15, no. 2, 2015.

[3] Z. Rasyid, "Faktor-Faktor yang Berhubungan dengan Kejadian Pneumonia Anak Balita di RSUD Bangkinang Kabupaten Kampar Factors Associated With Occurenceof Childhood Pneumonia In Bangkinang Hospital Kampar Regency," vol. 2, no. 5, pp. 136-140, 2013.

[4] A. I. G. Heni Sulastri, "Jurnal Teknologi dan Sistem Informasi PENERAPAN DATA MINING DALAM PENGELOMPOKAN PENDERITA," Teknol. dan Sist. Inf., vol. 2, pp. 299-305, 2017.

[5] T. Khotimah, "Pengelompokan Surat Dalam Al Qur'an Menggunakan Algoritma K-Means," Simetris, vol. 5, no. 1, pp. 83$88,2014$. 